\title{
Effect of Vitamin E Levels on the Cell-Mediated Immunity of Broilers Vaccinated Against Coccidiosis
}

-Author(s)

Silva ICM da ${ }^{1 b}$

Ribeiro $\mathrm{AML}^{1 \mathrm{ab}}$

Canal CW'ab

Vieira $\mathrm{MM}^{10}$

Pinheiro $\mathrm{CC}^{1 \mathrm{c}}$

Gonçalves $T^{10}$

de Moraes $\mathrm{ML}^{10}$

Ledur VS ${ }^{1 d}$

Departamento de Zootecnia.

2 Laboratório de Virologia, Departamento de

Patologia Clínica Veterinária.

a Professor.

b CNPq Researcher.

CAPES Researcher.

d Ungraduated student.

\section{Mail Adress}

Isabel Cristina Mello da Silva

Departamento de Zootecnia, UFRGS

Av. Bento Gonçalves, n 7712

91.529-000. Porto Alegre, RS, Brazil

E-mail: imellodasilva@gmail.com

\section{- Keywords}

Broiler, coccidiosis, cell-mediated immune response, Newcastle disease, vaccine, vitamin E.

\begin{abstract}
Studies on the relationships between animal nutrition and immunity have sought reliable methodologies to measure responses. Cellmediated immune response is similarly studied in humans. The cutaneous basophil hypersensitivity test $(\mathrm{CBH})$ is one of the methods to measure that response and consists in the infiltration of inflammatory cells, particularly of lymphocytes and basophils, as result of the application of substances capable of inducing cell proliferation in determined sites, such as wings, wattle, and interdigital space in birds. $\mathrm{CBH}$ is considered a simple and fast method and can be applied in birds of different ages. In immunocompetence studies with poultry, phytohemagglutinin-P (PHA-P) is a commonly used substance, despite the variability of the response related to the method of application (intradermal injection) and the antigens used. In the present experiment, PHA-P was used to observe the cell-mediated immune response of 216 chicks fed three dietary levels of vitamin E from 1 to 36 days of age. All birds were immunologically challenged by vaccination against coccidiosis at three days of age and against Newcastle Disease (NCD) at 14 and 30 days of age. At 36 days of age, birds were submitted to the $\mathrm{CBH}$ test according to the methodology of Corrier \& DeLoach (1990). Birds fed $65 \mathrm{mg} / \mathrm{kg}$ of vitamin E presented lasting cell reaction $(p \leq 0.08)$, which indicates that this vitamin E level improved cell immune response of birds due to its antioxidant and immunomodulating properties. The use of this vitamin E level can be considered by nutritionists under practical conditions, aiming to improve broiler immunity.
\end{abstract}

\section{INTRODUCTION}

In studies with birds which objective is to evaluate the immune responses and in which nutrients are manipulated to enhance bird immunity, not only performance responses are used. As the immune system is very complex, and some parameters are influenced by related sub-systems, immune responses are also used. Cell-mediated immune response is one of that methodologies applied in this kind of research as an auxiliary tool.

Cutaneous basophil hipersensitivity $(\mathrm{CBH})$ test consists of an intradermal injection of phytohemagglutinin-P (PHA-P) in the skin between the $3^{\text {rd }}$ and $4^{\text {th }}$ interdigital space of chickens, where the thymus-dependent reaction mediated by T cells is easy to analyze. This test can be performed in birds of up to two weeks of age, according Stadecker et al., (1977) but other authors (Boa-Amponsen et al., 2000; Sakamoto et al. 2006) have applied it in older birds.

Corrier \& Deloach (1990) used this method to evaluate the interdigital skin space between the toes of chickens as a skin-test site for eliciting $\mathrm{CBH}$ responses after the administration of dexamethasone. The authors 
Silva ICM da, Ribeiro AML, Canal CW, Vieira MM, Pinheiro CC, Gonçalves T, de Moraes ML, Ledur VS

concluded that the $\mathrm{CBH}$ test with PHA-P is a simple and fast method to evaluate of cell-mediated immunity in chickens. Sakamoto et al. (2006) also used this method in 36-day-old chickens, whereas Boa-Amponsen et al. (2000) used 90-day-old birds.

In 1959, the mitogenic properties of PHA-P were discovered. These properties are characterized by T-cell stimulation in several animal species, such as rats, mice, guinea-pigs, and birds. In humans, this method is applied in hypersensitivity tests ("late-phase reactions"; Goto et al., 1978). PHA-P is a glycoprotein of non-immune origin present in many varieties of beans, such as Phaseoulus vulgaris (SIGMA-Aldrich ${ }^{\circledR}$, particularly in red kidney beans.

Vitamin $E$ is one of the most frequent studied nutrients presenting immunomodulating properties, as it is a natural antioxidant of cell membranes and improves the phagocytic activity of macrophages (Konjufca et al., 2004), among another biological actions. Research on the effect of that vitamin on the immune response of poultry have yielded controversial results. For instance, vitamin levels that have some effect on immune parameters usually do not affect others, such as skin cell response. Sakamoto et al. (2006) observed higher cell proliferation feeding broilers with $10 \mathrm{mg} / \mathrm{kg}$ vitamin E as compared to 500 $\mathrm{mg} / \mathrm{kg}$. Leshchinsky \& Klasing (2001) did not observe any effect of 0 to $200 \mathrm{mg} / \mathrm{kg}$ of vitamin E dietary levels on the CBH test, and Boa-Amponsem et al. (2000) found lower reaction using $300 \mathrm{mg} / \mathrm{kg}$ vitamin $\mathrm{E}$ as compared to $10 \mathrm{mg} / \mathrm{kg}$ in rooster diets.

The aim of the present study was to study the effects of vitamin $E$ levels (levels similar to those recommended under practical situations) on the cellmediated immunity of broilers submitted to vaccine challenge, and to validate the $\mathrm{CBH}$ test as a method in this type of experiment.

\section{MATERIALS AND METHODS}

\section{Birds, housing, and treatments}

Two hundred and sixteen one-day-old Ross 308 male chicks were used in the experiment. Birds were housed in metal battery cages (at $0.72 \mathrm{~m}^{2} / \mathrm{cage}$ during the starter phase and $0.84 \mathrm{~m}^{2} / \mathrm{cage}$ during the grower phase) placed in a room with temperature control in the experimental facilities of the Laboratório de Ensino Zootécnico (LEZO) of the Federal University of Rio Grande do Sul, Brazil. Birds were offered the experimental diets and water ad libitum from day one. The lighting program used was 24 hours of artificial
Effect of Vitamin E Levels on the Cell-Mediated Immunity of Broilers Vaccinated Against Coccidiosis

light during the entire experimental period, which lasted 36 days.

The experiment was carried out according to a completely randomized design, with three dietary vitamin E levels and six replicates of 12 birds/replicate from day one to day 29, when this number was adjusted for 10 birds/replicate.

The experimental diets were manufactured from a basal diet, which was formulated using the Brazilian Tables for Poultry and Swine (Rostagno, 2005). Three vitamin E levels $(30,65$ and $100 \mathrm{mg} / \mathrm{kg}$ ) were added to the basal diet to establish the treatments (Table 1). Vitamin $\mathrm{E}$ was added as $50 \%$-tocopherol (BASF ${ }^{\circledR}$ ). The experimental diets were analyzed for dry matter and crude protein content (Animal Nutrition Laboratory of UFRGS). Vitamin E content in the experimental diets was analyzed by a commercial lab (CBO Assessoria e Análises, Campinas, SP, Brazil). Dry matter, crude protein, and vitamin $\mathrm{E}$ content were within the expected range. Diet composition is shown in Table 1.

\begin{tabular}{|c|c|c|}
\hline \multicolumn{3}{|c|}{$\begin{array}{l}\text { Table } 1 \text { - Ingredients composition and nutritional levels of the } \\
\text { basal diets. }\end{array}$} \\
\hline Ingredients (\%) & Starter & Grower \\
\hline Corn & 53.55 & 59.57 \\
\hline Soybean meal $45 \% \mathrm{CP}$ & 38.93 & 33.34 \\
\hline Monodibasic Phosphate & 1.43 & 1.21 \\
\hline Limestone & 1.35 & 1.38 \\
\hline Vegetable oil & 3.84 & 3.51 \\
\hline Salt & 0.41 & 0.43 \\
\hline DL-methionine & 0.207 & 0.214 \\
\hline L-Lysine $\mathrm{HCl}$ & 0.129 & 0.197 \\
\hline Choline $\mathrm{HCl} 60 \%$ & 0.06 & 0.05 \\
\hline Mineral-vitamin premix ${ }^{1}$ & 0.1 & 0.1 \\
\hline Total & 100 & 100 \\
\hline \multicolumn{3}{|l|}{ Calculated Nutrients } \\
\hline Crude protein \% & 22.0 & 20.00 \\
\hline $\mathrm{ME}, \mathrm{kcal} / \mathrm{kg}$ & 3,050 & 3,100 \\
\hline Calcium, $\%$ & 0.9 & 0.85 \\
\hline Available phosphorus, \% & 0.4 & 0.35 \\
\hline Sodium, $\%$ & 0.2 & 0.21 \\
\hline Chloride, \% & 0.27 & 0.29 \\
\hline Digestible Lys, $\%$ & 1.15 & 1.07 \\
\hline Digestible Met, $\%$ & 0.49 & 0.48 \\
\hline Digestible Met+Cys \% & 0.81 & 0.77 \\
\hline Digestible Thr, \% & 0.78 & 0.71 \\
\hline Choline, $\mathrm{mg} / \mathrm{kg}$ & 1,420 & 1,300 \\
\hline Vitamin $\mathrm{E}, \mathrm{mg} / \mathrm{kg}^{2}$ & 13.9 & 12.7 \\
\hline \multicolumn{3}{|c|}{ 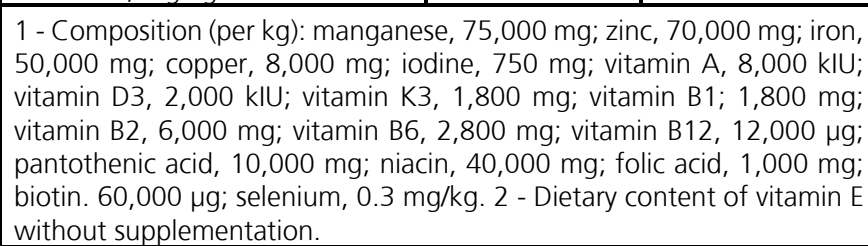 } \\
\hline
\end{tabular}


Silva ICM da, Ribeiro AML, Canal CW, Vieira MM, Pinheiro CC, Gonçalves T, de Moraes ML, Ledur VS

\section{Immune stimulation}

At three days of age, chicks were vaccinated against coccidiosis (Livacox $\mathrm{Q}^{\circledR}$, Merial) at a dose of $10 \mathrm{~mL} / 4 \mathrm{~L}$ of water distributed in $110 \mathrm{~mL}$ in each drinker placed in each cage. The floor of the cages was lined with paper for 16 days after vaccination to allow re-infestation of birds with the excreted oocysts.

At 14 and 30 days of age, birds were vaccinated by eyedrop against Newcastle Disease (NCD) (New Vac $L S^{\circledR}$, Fort Dodge). When birds were 35 days old, phytohemagglutinin (PHA-P) was applied at dose of $100 \mu \mathrm{g} / \mathrm{bird}$ in three birds/replicate. The cell reaction caused by the PHA-P injection was evaluated as cutaneous basophil hipersensitivity $(\mathrm{CBH})$ according to the methodology described by Corrier \& DeLoach (1990). PHA-P was purchased from SIGMA Aldrich ${ }^{\circledR}$ (PHA-P code number L8754 - lectin from Phaseolus vulgaris), and $15 \mathrm{mg}$ of the lyophilized powder were diluted in $15 \mathrm{~mL}$ of phosphate buffered saline solution (PBS) in order to obtain a dose of $100 \mu \mathrm{g} / 0.1 \mathrm{~mL}$ per bird. The inoculation was made in the interdigital space between the third and fourth toes of right foot of three birds/replicate, by intradermal injection. In the same interdigital space of the left foot (in the same bird), $0.1 \mathrm{~mL}$ PBS was injected as control.

\section{Measurements}

The thickness of interdigital spaces were measured before the injection and six, 12 and 24 hours afterwards using a digital caliper (Eletronic Digital Caliper CE, with $0.01 \mathrm{~mm}$ precision). The results were used to calculate the following:

(1) response $=$ post-PHA-P injection thickness of the right foot - pre-PHA-P injection thickness of the right foot $(\mathrm{mm})$

(2) PBS control response $=$ post-PBS injection thickness of the right foot - pre-PBS injection thickness of the left foot $(\mathrm{mm})$

Therefore, cell reaction at each evaluation time was calculated as:

$$
\mathrm{CBH}=(1)-(2)
$$

\section{Statistical analysis}

Experimental data normality was verified, and then data were submitted to analysis of variance, using SAS (2000) software package. Means were compared using least-square means test.
Effect of Vitamin E Levels on the Cell-Mediated Immunity of Broilers Vaccinated Against Coccidiosis

\section{RESULTS AND DISCUSSION}

Figure 1 shows that the vitamin E dietary level of $65 \mathrm{mg} / \mathrm{kg}$ provided the longer lasting cell-mediated immune response $(p \leq 0.08)$, as $24 \mathrm{~h}$ post-PHA-P injection, the skin in the interdigital space of birds fed that vitamin level was still very thick.

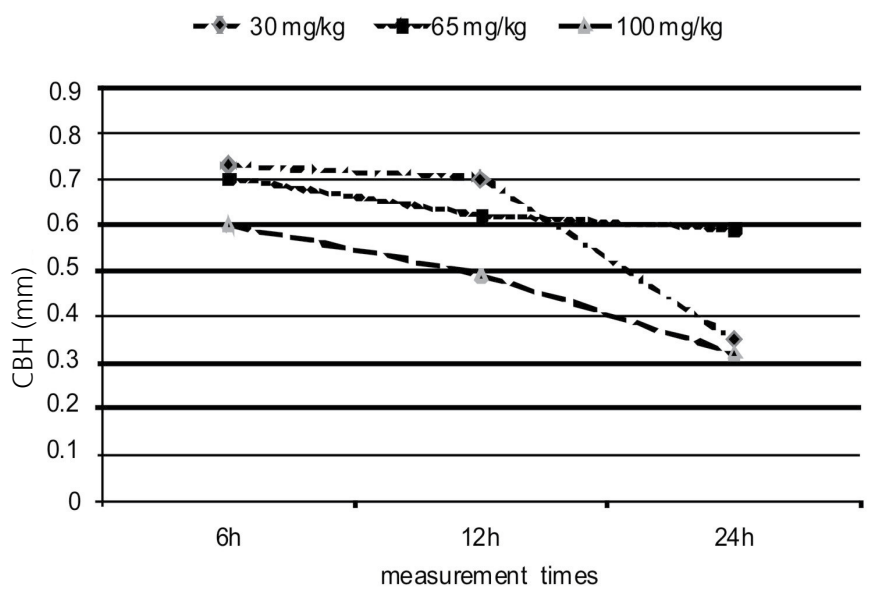

Figure 1 - Digital space skin thickness as a function of time after PHA-P injection of birds vaccinated against coccidiosis and consuming 30,65 and $100 \mathrm{mg} / \mathrm{kg}$ vitamin $\mathrm{E}$ in the diet.

The measured response is called cell-mediated response, which function is to eliminate intracellular antigens, which requires the release of cytokines by $T$ "helper" lymphocytes or Th1 (Erf. 2004). This response, along with humoral immunity and innate immunity, comprise the sub-systems of immune system. Opposite to the innate system, which is nonspecific and has several negative effects on the body, such as fever and anorexia (Humphrey \& Klasing, 2004), the cellmediated immune response is able of recognize a large number of intracellular antigens through of T-cell receptors and to eliminate them. Cytokines are also secreted during cell-mediated immune response: cell surface molecules are expressed, sending out activation signals to the other cells of the innate and adaptive systems (Erf. 2004).

Cell-mediated immune responses usually do not affect broiler performance, as observed by Konjufca et al. (2004) and Sakamoto et al. (2006). On the other hand, Koustsos et al. (2007) suggest that, due to the variability of results obtained in $\mathrm{CBH}$ tests, skin thickness increase at the site of PHA-P injection could also reveal innate immune reaction processes and not only cell-mediated reactions. Those authors have made biopsies and cell identification of lesions 
Silva ICM da, Ribeiro AML, Canal CW, Vieira MM, Pinheiro CC, Gonçalves T, de Moraes ML, Ledur VS
Effect of Vitamin E Levels on the Cell-Mediated Immunity of Broilers Vaccinated Against Coccidiosis

caused by PHA-P, and observed that the increase of skin thickness at the site of injection can be caused by a high influx of macrophages and heterophils, and not only of basophils and lymphocytes. This suggests that there are innate immune reactions or interactions between various types of leucocytes and not merely a single cell-mediated reaction. Corrier \& DeLoach (1990) also reported diffuse infiltration of neutrophils and basophils, as well as of lymphocytes and monocytes in their histopathological study in similar lesions. They also observed maximum cellular reaction $12 \mathrm{~h}$ post-PHA-P injection, and that this reaction remained constant or slightly declined $24 \mathrm{~h}$ post-injection.

Koustsos et al. (2007) studied the influence of carotenoids, especially of lutein, on the cutaneous basophil responses in chickens and found local cell reactions up to $48 \mathrm{~h}$ post-PHA-P injection. The authors believe that because lutein can activate lymphocyte multiplication and is also able to reduce the production of free radicals, it may interfere in the local reaction to PHA-P. In the present experiment, the cell types present in the local lesions were not studied, but as vitamin E acts as antioxidant similarly to lutein, the dietary vitamin E level of $65 \mathrm{mg} / \mathrm{kg}$ could contribute for the longer lasting cell reactions found.

When testing vitamin $E$ levels associated or not to glutamine in broiler diets, Sakamoto et al. (2006) observed higher cell proliferation $12 \mathrm{~h}$ post-PHA-P injection in birds consuming $10 \mathrm{mg} / \mathrm{kg}$ than in those consuming $500 \mathrm{mg} / \mathrm{kg}$. On the other hand, Leshchinsky \& Klasing (2001), using 0 to $200 \mathrm{mg} / \mathrm{kg}$ vitamin E in broiler diets, did not observe any effects on $\mathrm{CBH}$. BoaAmponsem et al. (2000) obtained lower CBH with $300 \mathrm{mg} / \mathrm{kg}$ vitamin $\mathrm{E}$ than with $10 \mathrm{mg} / \mathrm{kg}$ in rooster diets. The authors emphasized that the $\mathrm{CBH}$ method can lead to variable responses because of the difficulty to do a perfect application (intradermal injection) of the PHA-P effective dose. This could explain the high coefficients of variation found for this response.

\section{CONCLUSIONS}

The results obtained for the group of birds consuming $65 \mathrm{mg} / \mathrm{kg}$ of vitamin $\mathrm{E}$ showed that this level is effective for the enhancement of the immune response as evaluated by the $\mathrm{CBH}$ test in birds challenged with the vaccine against coccidiosis. Under practical conditions, this level of vitamin $\mathrm{E}$ can be used by poultry nutritionists. Despite the variability of responses, the $\mathrm{CBH}$ test is useful in studies on nutrition related to immunity.

\section{REFERENCES}

Boa-Amponsem K, Price SEH, Picard M, Meldrum B, Siegel PB. Vitamin $E$ and immune responses of broiler pureline chickens. Poultry Science 2000; 79:466-470.

Erf GF. Cell-mediated immunity in poultry. Poultry Science 2004; $83: 590-580$

Corrier DE, DeLoach JR. Evaluation of cell mediated cutaneous basophil hipersensitibility in young chickens by an interdigital skin test. Poultry Science 1990; 69:403-408.

Goto N, Kodama H, Okada K, Fujimoto Y. Suppression of phytohemagglutinin skin response in tymectomized chickens. Poultry Science 1978; 57:246-250.

Humphrey BD, Klasing KC. Modulation of nutrient metabolism and homeostasis by the immune system. World's Poultry Science Journal 2004; 60:90-100.

Konjufca VK, Bottje WG, Bersi K, Erf GF. Influence of dietary vitamin $E$ on phagocytic functions of macrophages in broilers. Poultry Science 2004; 83:1530-1534.

Koutsos EA, López JGC, Klasing KC. Maternal and dietary carotenoids interactively affect cutaneous basophil responses in growing chickens (Gallus gallus domesticus). Comparative Biochemestry and Phisiology part B 2007; 147:87-92.

Leshchinsky TV, Klasing KC. Relationship between the level of dietary vitamin $\mathrm{E}$ and immune response of broiler chickens. Poultry Science 2001; .80:1590-1599.

National Research Council - NRC. Nutrient requirements of poultry. 9thed. Washington: National Academy Press; 1994.

Rostagno HS. Composição dos alimentos e exigências nutricionais para aves: tabelas brasileiras para aves e suínos: Brazilian tables for birds and swine. Viçosa (MG): UFV; 2005.

Sakamoto MI, Murakami AE, Silveira TGV, Fernandes JIM, Oliveira $\mathrm{CAL}$ de. Influence of glutamine and vitamin $\mathrm{E}$ on the performance and the immune responses of broiler chickens. Brazilian Journal of Poultry Science 2006; 8(4):243-249.

Stadecker MJ, Lukic M, Dvorak A. Leskowitz S. The cutaneous basophil response to phytohemagglutinin in chickens. Journal of Immunology 1977; 118:1564-1568. 